Vol. 2 No. 2 (2021), Halaman 142-149

ISSN 2774-6968
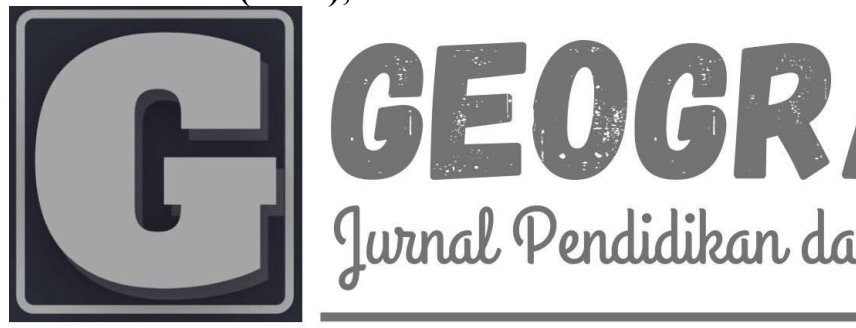

AP

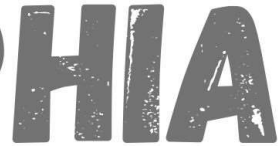

Pendidikan dan Pen

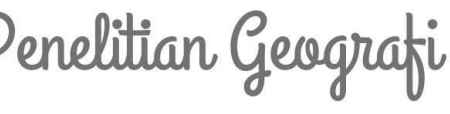

\title{
KAJIAN FAKTOR GEOGRAFI PADA PERTUMBUHAN USAHA KECIL NON PERTANIAN DI DESA BORONA DAN DESA TIBOBO KABUPATEN HALMAHERA BARAT
}

\author{
Alson Ungu ${ }^{1}$, Grystin Djein Sumilat ${ }^{2}$, Hermon Maurits Karwur ${ }^{3}$ \\ ${ }^{1}$ Jurusan Pendidikan Geografi, Universitas Negeri Manado \\ Email: alsonungu@gmail.com \\ ${ }^{2}$ Program Studi Pendidikan IPS, Universitas Negeri Manado \\ Email: grystin_sumilat@unima.ac.id \\ ${ }^{3}$ Program Studi Pendidikan IPS, Universitas Negeri Manado \\ Email: hermonkarwur@unima.ac.id \\ Website Jurnal: http://ejurnal.unima.ac.id/index.php/geographia \\ DOI: $10.53682 /$ gjppg.v2i2.864 \\ (Diterima: 14-02-2021; Direvisi: 09-11-2021; Disetujui: 12-11-2021)
}

\begin{abstract}
The study of geographic factors (distance and location) is the background of this research. The objectives of this study are 1). To study geographic factors that support the growth of small nonagricultural enterprises in Borona Village and Tibobo Village, West Halmahera Regency, 2). This is to determine the contribution of small non-agricultural businesses to job opportunities in Borona Village and Tibobo Village, West Halmahera Regency. The research method is quantitative. According to the research objectives, two villages were selected that have different geographic factors (distance from the city center), namely Borona Village, Ibu District, representing villages far from Jailolo City (72 km) and Tibobo Village, Sahu District, representing villages close to Jailolo City (9 km). ). The results showed that geographic factors (distance from the city center) influenced the growth of small nonagricultural enterprises in the two research locations. Of the total 211 business units, 142 business units (67.30\%) are located in Tibobo Village which is located close to the center of Jailolo City compared to Borona Village which is located far from the center of Jailolo City which only has 69 types of businesses or $32.70 \%$. The workforce is absorbed in non-agricultural small businesses which are spread over 3 business groups consisting of 16 types of businesses and covering 211 business units.
\end{abstract}

Keywords: Geographical factors, Non-agricultural small businesses, Farmers.

\section{ABSTRAK}

Kajian tentang faktor geografi (jarak dan lokasi) menjadi latar belakang penelitian ini. Tujuan penelitian ini adalah: 1). Untuk mengkaji faktor geografi yang menunjang pertumbuhan usaha kecil non pertanian di di Desa Borona dan Desa Tibobo Kabupaten Halmahera Barat, 2). Untuk mengetahui kontribusi usaha-usaha kecil non pertanian terhadap kesempatan kerja di Desa Borona dan Desa Tibobo Kabupaten Halmahera Barat. Metode penelitian adalah metode kuantitatif. Sesuai tujuan penelitian, maka dipilih dua desa yang memiliki perbedaan faktor geografi (jarak dengan pusat kota) yaitu Desa Borona Kecamatan Ibu mewakili desa yang jauh dari Kota Jailolo (72 km) dan Desa Tibobo Kecamatan Sahu mewakili desa yang dekat dengan Kota Jailolo $(9 \mathrm{~km})$. Hasil penelitian menunjukkan 
bahwa faktor geografi (jarak dari pusat kota) memiliki pengaruh terhadap pertumbuhan usaha kecil non pertanian di dua lokasi penelitian. Dari total 211 unit usaha, sebanyak 142 unit usaha (67,30\%) terdapat di Desa Tibobo yang terletak dekat dengan pusat Kota Jailolo dibandingkan dengan Desa Borona yang terletak jauh dari pusat Kota Jailolo hanya memiliki 69 jenis usaha atau 32,70\%. Tenaga kerja yang terserap pada usaha-usaha kecil non pertanian yang tersebar pada 3 kelompok usaha yang terdiri dari 16 jenis usaha dan mencakup 211 unit usaha.

Kata Kunci: Faktor geografi, Usaha kecil non pertanian, petani

\section{PENDAHULUAN}

Di negara-negara sedang berkembang khususnya di Indonesia, sektor pertanian mendapat perhatian yang cukup berarti dalam perencanaan dan kebijakan pembangunan ekonomi nasional. Menurut (Aninditya et al., 2020), salah satu alasan mengapa sektor pertanian perlu dibangun terlebih dahulu adalah bahwa barang-barang hasil industri memerlukan dukungan daya beli masyarakat. Karena sebagian besar calon pembelinya adalah masyarakat petani yang merupakan mayoritas penduduk negara-negara sedang berkembang, maka tingkat pendapatan mereka perlu ditingkatkan melalui pembanguan pertanian.

Keberhasilan sektor pertanian sebagai sektor ekonomi primer yang merupakan mata pencaharian pokok mayoritas penduduk Indonesia di perdesaan telah berhasil meningkatkan produksi beras ke tingkat swasembada dan meningkatkan penghasilan masyarakat perdesaan. Namun kontribusi sektor ini terhadap penciptaan peluang kerja khususnya pekerjaan non pertanian, masih sangat terbatas. Masalah tenaga kerja di perdesaan antara lain disebabkan oleh peningkatan angkatan kerja yang tidak seimbang dengan peluang kerja baru. Pertumbuhan tenaga kerja yang lebih besar dibandingkan dengan ketersediaan lapangan kerja menyebabkan pengangguran yang tinggi (Ardiansyah et al., 2018).

Hal ini disebabkan oleh pengaruh negatif intensifikasi pertanian yang telah menurunkan daya serap sektor pertanian, merubah hubungan kerja, dan memacu konsentrasi pemilikan lahan pertanian. Situasi ini mendorong sebagian petani dan buruh tani mencari peluang kerja di luar sektor pertanian. Sebaliknya, pengaruh positif intensifikasi pertanian menyebabkan perluasan kesempatan kerja di sektor pertanian. Hal ini terjadi karena intensifikasi memungkinkan diversivikasi pertanian, peningkatan produksi dan peningkatan penghasilan yang dapat diinvestasikan ke luar sektor pertanian seperti industri rumah tangga, perdagangan, dan jasa.

Selanjutnya (Harmadi \& Tjiptoherijanto, 2009), mengemukakan keterbatasan kemampuan sektor pertanian dalam menyerap tambahan angkatan kerja pedesaan menyebabkan peluang kerja menjadi masalah yang krusial. Oleh karena itu, perlu dipikirkan strategi yang mampu menciptakan peluang kerja, terutama peluang kerja bukan pertanian (non-farm employment). Pentingnya peluang kerja bukan pertanian dalam strategi perluasan peluang kerja pedesaan karena mempunyai tiga fungsi dalam pengembangan pedesaan, yaitu: pertama, peluang kerja bukan pertanian secara langsung dapat meransang perluasan peluang kerja bagi angkatan kerja pedesaan, karena mempunyai potensi untuk menciptakan peluang kerja tanpa harus didukung oleh modal besar dan mampu menyerap banyak pekerja. Artinya, peluang kerja bukan pertanian dapat mengatasi masalah lapangan kerja pedesaan yang sering terbentur pada kendala permodalan. Dengan demikian, besar kemungkinan bagi tenaga kerja untuk memasuki peluang kerja ini. Kedua, dapat berperan sebagai sumber penghasilan yang penting bagi rumah tangga pedesaan, terutama rumah tangga tani miskin yang sempit tanah garapannya atau yang tidak memiliki tanah/petani gurem (Suhariyanto, 2007).

Dengan adanya peluang kerja bukan pertanian, petani berlahan sempit bisa mendapatkan penghasilan lain yaitu dengan memasuki peluang kerja bukan pertanian. Ketiga, peluang kerja bukan pertanian mempunyai efek keterkaitan dengan pengembangan pertanian dan industri, yang acapkali dilupakan dalam strategi pengembangan pedesaan. Di samping itu, peluang kerja bukan pertanian dapat menahan arus migrasi desa-kota dan merangsang pertumbuhan kota-kota kecil.

Ekonomi non pertanian di pedesaan muncul sebagai salah satu kunci yang 
memberikan kontribusi terhadap pertumbuhan ekonomi, angkatan tenaga kerja, penggolongan mata pencaharian, dan pengurangan tingkat kemiskinan di negara berkembang (Amwar, 2014). Peluang kerja non pertanian sering berbentuk UMKM (Usaha Mikro Kecil dan Menengah) yang bergerak dalam sektor-sektor informal terutama perdagangan barang dan jasa. UMKM mempunyai peranan penting dalam kegiatan ekonomi non pertanian adalah sebagai penciptaan sumber pendapatan alternatif bagi masyarakat miskin (Purwanto, 2007). Peran kegiatan non pertanian sebagai alternatif atas dasar beberapa permasalahan yang terjadi pada sektor pertanian.

Beberapa permasalahan sektor pertanian yang dapat diidentifikasi adalah sebagai berikut 1) luas lahan pertanian padi sawah dalam waktu lima tahun terakhir telah mengalami penurunan disebabkan karena sebagian lahan pertanian sawah telah direklamasi untuk pembangunan berbagai fasilitas pemerintah dan fasilitas pelayanan umum. 2) fungsi lahan pertanian sawah untuk pembangunan berbagai fasilitas pemerintah dan fasilitas umum maka sebagian masyarakat telah beralih profesi dari sektor pertanian ke sektor-sektor non pertanian. 3) pertumbuhan berbagai aktivitas ekonomi atau usaha kecil non pertanian seperti industri rumah tangga/kerajian, perdagangan, dan aktivitas jasa.

Faktor geografis yang dimaksud dalam penelitian ini adalah lokasi absolut yaitu jarak antara kedua lokasi penelitian dengan pusat Kabupaten Halmahera Barat sebagai pusat aktivitas ekonomi yang menunjang pertumbuhan usaha kecil non pertanian, diukur dalam satuan $\mathrm{km}$. Usaha kecil non pertanian yang dimaksud dalam penelitian ini adalah tipe kegiatan ekonomi non pertanian berskala kecil yang meliputi industri kecil atau industri rumah tangga dan kerajinan, perdagangan eceran seperti padagang bahan makanan, pedagang buah dan sayuran, pedagang makanan masak (kios/rumah makan), pedagang barang-barang kelontongan, dan aktivitas jasa seperti jasa kesehatan, salon kecantikan, pangkas rambut, dll, diukur dalam satuan unit usaha atau banyaknya unit usaha. Kesempatan kerja adalah jumlah tenaga kerja yang bekerja atau terserap pada usaha-usaha kecil non pertanian di dua lokasi penelitian, diukur dalam satuan orang atau banyaknya tenaga kerja pada masingmasing unit usaha.

\section{METODE PENELITIAN}

Penelitian ini termasuk jenis penelitian deskriptif kuantitatif. Penelitian deskriptif bertujuan untuk membuat pencandraan (deskripsi) secara sistematis, faktual, dan akurat mengenai fakta-fakta dan sifat-sifat populasi atau daerah tertentu. Dalam hal ini penelitian deskriptif adalah akumulasi data dasar dalam cara deskriptif semata-mata dan tidak perlu mencari atau menerangkan saling hubungan, menguji hipotesis, membuat ramalan, atau mendapatkan makna dan implikasi.

Mengacu pada rumusan masalah dan tujuan penelitian, maka dalam penelitian ini terdapat tiga variabel pokok sebagai berikut 1) faktor geografi, 2) usaha kecil non pertanian dan 3) kesempatan kerja

\section{HASIL PENELITIAN Analisi Usaha Non Pertanian}

Hasil analisis data menunjukkan bahwa usaha kecil non pertanian di dua lokasi penelitian mencakup tiga kelompok usaha yaitu: 1) kelompok usaha industri kecil/rumah tangga yang terdiri dari 4 jenis usaha: industri mebel, pande besi, pabrik tahu, dan kerajinan bambu/anyaman; 2) kelompok usaha perdagangan eceran yang terdiri dari 5 jenis usaha: kios/warung barang kebutuhan pokok, kios/warung barang kelontong, mini market, rumah/warung makan, dan pedagang keliling; 3) kelompok usaha jasa yang terdiri dari 7 jenis usaha: hotel/penginapan, wartel/jastel, angkutan penumpang, fotokopi/penjilidan, rental komputer, dokter praktek umum, dan salon kecantikan. Tabel 1 menyajikan distribusi usaha kecil non pertanian di dua lokasi penelitian yang berbeda jaraknya ke pusat kota, yaitu Desa Tibobo yang terletak dekat pusat kota $(9 \mathrm{~km})$ dan Desa Borona yang terletak jauh dari pusat kota $(72 \mathrm{~km})$.

Data pada Tabel 1. menunjukkan perbedaan baik jumlah maupun variasi kelompok dan jenis usaha kecil non pertanian di dua lokasi penelitian (Desa Tibobo dan Desa Barona) yang berbeda jaraknya ke pusat kota Jailolo sebagai pusat kabupaten. Secara keseluruhan, jenis usaha kecil non pertanian terbanyak terdapat di Desa Tibobo yang letaknya lebih dekat $(9 \mathrm{~km})$ dengan pusat Kota Jailolo dibandingkan dengan Desa Borona yang relatif jauh $(72 \mathrm{~km})$ dengan pusat kota kabupaten. 
Dari total 211 unit usaha, sebanyak 142 unit usaha terdapat di Desa Tibobo atau mencakup $67,30 \%$ total unit usaha, sedangkan di Desa Borona hanya terdapat 69 unit usaha atau mencakup 32,70\% total unit usaha. Dilihat menurut kelompok usaha, sebagian besar

Tabel 1.

Usaha Kecil Non Pertanian di Dua Lokasi Penelitian Menurut Kelompok dan Jenis Usaha

\begin{tabular}{|c|c|c|c|}
\hline $\begin{array}{l}\text { Kelompok/ } \\
\text { Jenis usaha }\end{array}$ & $\begin{array}{c}\text { TIBOBO } \\
\text { (dekat pusat } \\
\text { kota) }\end{array}$ & $\begin{array}{c}\text { BORONA } \\
\text { (jauh pusat kota) }\end{array}$ & Jumlah (unit) \\
\hline \multicolumn{4}{|l|}{ Industri kecil/rumah tangga: } \\
\hline 1.1. Industri mebel & 62 & 7 & 69 \\
\hline 1.2. Pande besi & 11 & 4 & 15 \\
\hline 1.3. Pabrik tahu & 2 & 3 & 5 \\
\hline 1.4. Kerajinan anyaman & 8 & 23 & 31 \\
\hline Sub Total 1 & $83(58,45 \%)$ & $37(53,62 \%)$ & $120(56,87 \%)$ \\
\hline \multicolumn{4}{|l|}{ Perdagangan eceran: } \\
\hline 1.1. Kios/warung barang kebutuhan pokok & 12 & 7 & 19 \\
\hline 1.2. Kios/warung barang kelontong & 3 & 2 & 5 \\
\hline 1.3. Mini market & 3 & 1 & 4 \\
\hline 1.4. Rumah/warung makan & 2 & 1 & 3 \\
\hline 1.5. Pedagang keliling & 5 & 3 & 8 \\
\hline Sub Total 2 & $25(17,61 \%)$ & $14(20,29 \%)$ & $39(18,48 \%)$ \\
\hline \multicolumn{4}{|l|}{ J a s a: } \\
\hline 3.1. Hotel/penginapan & - & 1 & 1 \\
\hline 3.2. Wartel/Jastel & 5 & 3 & 8 \\
\hline 3.3. Angkutan darat & 12 & 9 & 21 \\
\hline 3.4. Foto copy/penjilidan & 6 & 2 & 8 \\
\hline 3.5. Rental komputer & 4 & 2 & 6 \\
\hline 3.6. Dokter praktek umum & 2 & - & 2 \\
\hline \multirow[t]{3}{*}{ 3.7. Salon kecantikan } & 5 & 1 & 6 \\
\hline & $34(23,94 \%)$ & $18(26,09 \%)$ & $\mathbf{5 2}(24,65 \%)$ \\
\hline & $142(100 \%)$ & $69(100 \%)$ & $211(100 \%)$ \\
\hline
\end{tabular}

Sumber: Hasil penelitian, 2019.

adalah kelompok usaha industri kecil / rumahtangga sebanyak 120 unit usaha $(56,87 \%)$ total unit usaha yang terdiri dari 4 jenis usaha yaitu industri mebel 69 unit usaha, pande besi 15 unit usaha, pabrik tahu 5 unit usaha dan kerajinan bambu/anyaman 31 unit usaha. Menyusul kelompok usaha jasa sebanyak 52 unit usaha $(24,65 \%)$ yang terdiri dari 7 jenis usaha yaitu hotel/penginapan 1 unit usaha, wartel/jastel 8 unit usaha, jasa angkutan darat 21 unit usaha, fotokopi/penjilidan 8 unit usaha, rental komputer 6 unit usaha, dokter praktek 2 unit usaha, dan salon kecantikan 6 unit usaha. Sedangkan kelompok usaha perdagangan pada urutan terakhir sebanyak 39 unit usaha $(18,48$ $\%)$ terdiri dari 5 jenis usaha yaitu kios/warung bahan kebutuhan pokok 19 unit usaha, kios barang kelontong 5 unit usaha, mini market 4 GEOGRAPHIA,Vol. 2 No. 2 (2021) unit usaha, rumah makan 3 unit usaha, dan pedagang keliling 8 unit usaha.

Di Desa Tibobo, dari 4 jenis industri kecil/rumah tangga, jenis usaha yang paling menonjol adalah industri mebel khususnya perabot rumah tangga (62 unit) kemudian pande besi (11 unit), sedangkan di Desa Borona terbanyak adalah kerajinan bambu (23 unit). Jenis usaha perdagangan yang terbanyak baik di Desa Tibobo maupun Desa Borona adalah kios/warung yang menyediakan kebutuhan pokok, dan untuk kelompok usaha jasa, jenis usaha yang banyak digeluti di dua lokasi penelitian adalah jasa angkutan darat khususnya angkutan penumpang baik dalam kota maupun antar kota. Selain itu, jasa wartel/jastel dan rental komputer juga menjadi pilihan mata 
pencaharian hidup penduduk di dua lokasi penelitian.

\section{Kesempatan Kerja (Penyerapan Tenaga Kerja)}

Sebagaimana dijelaskan dalam bagian definisi operasional variabel, kesempatan kerja yang dimaksud dalam penelitian ini adalah jumlah tenaga kerja yang bekerja atau terserap pada usaha-usaha kecil non pertanian di dua lokasi penelitian, diukur dalam satuan orang atau banyaknya tenaga kerja yang terserap pada setiap unit usaha. Distribusi tenaga kerja yang terserap pada 211 unit usaha disajikan dalam tabel berikut.

Tabel 2

Distribusi Penyerapan Tenaga Kerja Menurut Kelompok dan Jenis Usaha Kecil Non Pertanian

\begin{tabular}{|c|c|c|}
\hline KELOMPOK/JENIS USAHA & $\begin{array}{c}\text { BANYAK USAHA } \\
\text { (Unit) }\end{array}$ & $\begin{array}{c}\text { TENAGA KERJA } \\
\text { (Orang) }\end{array}$ \\
\hline \multicolumn{3}{|l|}{ 1. Industri kecil/rumah tangga: } \\
\hline 1.1. Industri mebel & 69 & 192 \\
\hline 1.2. Pande besi & 15 & 22 \\
\hline 1.3. Pabrik tahu & 5 & 10 \\
\hline 1.4. Kerajinan bambu/anyaman & 31 & 28 \\
\hline Sub Total 1 & 120 & $252(65,45 \%)$ \\
\hline \multicolumn{3}{|l|}{ 2. Perdagangan eceran: } \\
\hline 1.5. Kios/warung barang keb.pokok & 19 & 25 \\
\hline 1.6. Kios/warung barang kelontong & 5 & 7 \\
\hline 1.7. Mini market & 4 & 6 \\
\hline 1.8. Rumah/warung makan & 3 & 5 \\
\hline 1.9. Pedagang keliling & 8 & 8 \\
\hline Sub Total 2 & 39 & $51(18,48 \%)$ \\
\hline \multicolumn{3}{|l|}{ 3. J a s a: } \\
\hline 3.1. Hotel/penginapan & 1 & 7 \\
\hline 3.2. Wartel/Jastel & 8 & 8 \\
\hline 3.3. Angkutan darat & 21 & 34 \\
\hline 3.4. Foto copy/penjilidan & 8 & 13 \\
\hline 3.5. Rental komputer & 6 & 10 \\
\hline 3.6. Dokter praktek umum & 2 & 2 \\
\hline \multirow[t]{3}{*}{ 3.7. Salon kecantikan } & 6 & 8 \\
\hline & 52 & $82(21,30 \%)$ \\
\hline & 211 unit & 385 orang \\
\hline
\end{tabular}

Sumber: Hasil penelitian, 2019.

Hasil penelitian seperti terlihat pada tabel 4.9 menunjukkan bahwa tenaga kerja yang terserap pada usaha-usaha kecil non pertanian di dua lokasi penelitian seluruhnya berjumlah 385 orang. Jumlah tenaga kerja tersebut tersebar pada 3 kelompok usaha terdiri dari 16 jenis yang mencakup 211 unit usaha. Secara keseluruhan tenaga kerja terbanyak terserap pada jenis industri mebel yaitu 192 orang atau 49,87\% total tenaga kerja yang terserap pada semua unit usaha.

Jika dilihat menurut kelompok usaha, industri kecil/rumah tangga dengan 4 jenis usaha, menyerap tenaga kerja terbanyak yaitu 252 orang atau mencakup $65,45 \%$ total tenaga GEOGRAPHIA, Vol. 2 No. 2 (2021) kerja. Dari 252 orang tenaga kerja yang terserap pada kelompok ini, sebagian besar terserap pada jenis usaha industri mebel yaitu 192 orang $(76,19 \%)$, menyusul usaha kerajinan/anyaman sebanyak 11,11\%, usaha pande besi sebanyak 8,73 \%, dan usaha pembuatan tahu (3,97\%). Kemudian kelompok usaha jasa dengan 7 jenis usaha menyerap tenaga kerja 82 orang $(21,30 \%)$. Jenis usaha jasa angkutan darat (penumpang) menyerap paling banyak yaitu 34 orang $(41,46 \%)$ kemudian usaha fotocopy/penjilidan $(15,85 \%)$, usaha rental komputer (12,19\%), usaha wartel/jastel dan salon kecantikan masingmasing $9,76 \%$ dan jasa penginapan/hotel 8,54 
\%. Kelompok usaha perdagangan eceran dengan 5 jenis usaha menyerap sebanyak 51 orang tenaga kerja $(13,25 \%)$. Hampir separuh tenaga kerja pada kelompok usaha perdagangan terserap pada usaha kios/warung kebutuhan pokok yaitu 25 orang $(49,02 \%)$, kemudian usaha pedagang keliling $(15,69 \%)$, usaha kios barang kelontong $(13,72 \%)$, usaha mini market $(11,76 \%)$, dan usaha rumah makan sebanyak $9,80 \%$ total tenaga kerja.

\section{PEMBAHASAN \\ Faktor Geografi dan Usaha Kecil Non Pertanian}

Hasil analisis data menunjukkan bahwa faktor geografi atau jarak desa ke ibukota kabupaten memiliki pengaruh terhadap pertumbuhan usaha kecil non pertanian di dua desa tersebut sebagai lokasi penelitian. Dengan kata lain bahwa munculnya berbagai jenis usaha kecil di dua lokasi penelitian turut dipengaruhi oleh jarak kedua lokasi penelitian dengan pusat kota Jailolo sebagai ibukota kabupaten dan pusat aktivitas ekomomi penduduk.

Desa Tibobo yang terletak lebih dekat dengan pusat kota Jailolo $(9 \mathrm{~km})$ memiliki lebih banyak unit usaha kecil non pertanian baik kelompok usaha industri kecil/rumah tangga, kelompok usaha perdagangan eceran, maupun kelompok usaha jasa. Seperti tertera pada tabel 4.6, dari total 211 unit usaha, sebanyak 142 unit usaha atau $67,30 \%$ total unit usaha terdapat di Desa Tibobo yang terletak dekat dengan pusat kota. Persentase terbanyak adalah kelompok usaha industri kecil/rumah tangga sebanyak $58,45 \%$, kemudian kelompok usaha jasa 23,94 $\%$, dan paling sedikit kelompok usaha perdagangan eceran $17,61 \%$ total unit usaha. Di Desa Borona yang terletak $72 \mathrm{~km}$ dari pusat kota terdapat sebanyak 69 jenis usaha atau $32,70 \%$ total unit usaha di dua kelurahan tersebut. Kelompok usaha industri kecil/rumah tangga juga paling banyak yaitu 53,62 \%, menyusul kelompok usaha jasa $(26,09 \%)$, dan perdagangan eceran $(20,29 \%)$ total unit usaha di kelurahan tersebut.

Sebagaimana telah diuraikan dalam bagian latar belakang masalah bahwa perkembangan usaha kecil non pertanian khususnya industri rumah tangga, perdagangan, dan jasa tidak terlepas dari pengaruh perkembangan sebuah wilayah khususnya perkembangan fisik wilayah tersebut. Satu faktor wilayah yang berpengaruh terhadap pertumbuhan aktivitas ekonomi skala kecil adalah lokasi dalam hirarki wilayah (jarak dengan pusat kota atau pusat pelayanan). Dikemukakan bahwa secara teoritis daerah (desa/kelurahan) yang lokasinya relatif berdekatan dengan pusat kota mempunyai keunggulan menstimulir pertumbuhan usaha kecil non pertanian.

Dengan demikian, mengacu pada teori tersebut maka jelas bahwa perbedaan jumlah unit usaha di dua desa penelitian sebagaimana dikemukakan di atas merupakan pengaruh dari faktor lokasi atau jarak kedua desa tersebut dengan pusat Kota Jailolo sebagai pusat aktivitas ekonomi. Oleh karena itu, hasil penelitian ini sekaligus mendukung atau menguatkan pendapat Sutanto di atas yang digunakan sebagai landasan teori masalah dalam penelitian ini.

\section{Kesempatan Kerja}

Bermunculan usaha kecil non pertanian di dua lokasi penelitian telah memberikan dampak positif bagi penduduk sekitarnya dalam hal kesempatan kerja atau penyerapan tenaga kerja pada setiap unit usaha yang tersedia. Hal ini dapat dilihat dari hasil analisis data pada tabel 4.9 yang menunjukkan bahwa tenaga kerja yang terserap pada usaha kecil non pertanian di dua lokasi penelitian berjumlah 385 orang. Jumlah tersebut tersebar pada tiga kelompok usaha yang terdiri dari 16 jenis usaha dan mencakup 211 unit usaha. Kelompok usaha industri kecil/rumah tangga dengan 4 jenis usaha, menyerap tenaga kerja terbanyak mencakup $65,45 \%$ total tenaga kerja dan sebagian besar $(76,19 \%)$ dari jumlah tersebut terserap pada jenis usaha industri mebel. Kelompok usaha jasa dengan 7 jenis usaha menyerap tenaga kerja kedua terbanyak $(21,30$ $\%$ ) dan $41,46 \%$ di antaranya terserap pada jenis usaha jasa angkutan darat. Sedangkan kelompok usaha perdagangan dengan 5 jenis usaha menyerap 13,25\% total tenaga kerja dan hampir separuh tenaga kerja pada kelompok usaha ini terserap pada usaha kios/warung kebutuhan pokok yaitu sebanyak $49,02 \%$.

Penyerapan tenaga kerja yang cukup signifikan pada berbagai usaha kecil non pertanian di dua lokasi penelitian sebagaimana dikemukakan di atas, memberikan gambaran bahwa usaha kecil non pertanian merupakan alternatif yang cukup strategis dalam rangka mengatasi masalah kesempatan kerja di 
pedesaan. Hal ini mengingat adanya peningkatan angkatan kerja yang tidak seimbang dengan peluang kerja di sektor primer (khsususnya pertanian).

Pentingnya peranan usaha kecil non pertanian dalam strategi perluasan peluang kerja di perdesaan seperti dikemukakan oleh Effendi (1995) bahwa peluang kerja non pertanian secara langsung dapat merangsang perluasan peluang kerja bagi angkatan kerja pedesaan karena mempunyai potensi untuk menciptakan peluang kerja baru dan mampu menyerap banyak pekerja. Artinya, peluang kerja bukan pertanian dapat mengatasi masalah lapangan kerja pedesaan yang acapkali terbentur pada kendala permodalan. Dengan demikian, besar kemungkinan bagi tenaga kerja untuk memasuki peluang kerja ini. Strategi perluasan peluang kerja di pedesaan mengalami pergeseran fokus dari sektor pertanian (primer) ke sektor industri (sekunder) khususnya industri kecil, dan sektor perdagangan dan jasa (tersier). Sektor sekunder dan tersier khususnya usahausaha kecil mendapat perhatian yang serius dan dipandang sebagai komponen yang vital dan mendukung, baik untuk perncapaian tujuan pertumbuhan maupun pemerataan kesempatan kerja.

\section{KESIMPULAN}

Faktor lokasi sebagai salah satu faktor geografis memiliki pengaruh terhadap pertumbuhan usaha kecil non pertanian di dua lokasi penelitian. Munculnya berbagai jenis usaha kecil di dua lokasi penelitian turut dipengaruhi oleh faktor lokasi yaitu jarak kedua lokasi penelitian dengan pusat kota sebagai pusat aktivitas ekomomi penduduk. Dari total 211 unit usaha, sebagian besar yaitu 142 unit $(67,30 \%)$ terdapat di Desa Tibobo yang terletak dekat dengan pusat kota Jailolo $(9 \mathrm{~km})$ dibandingkan dengan Desa Borona yang terletak $72 \mathrm{~km}$ dari pusat kota hanya memiliki sebanyak 69 jenis usaha atau 32,70\% total unit usaha di dua desa tersebut.

Berbagai jenis usaha kecil non pertanian di dua lokasi penelitian telah memberikan dampak positif bagi penduduk sekitarnya dalam hal kesempatan kerja atau penyerapan tenaga kerja pada setiap unit usaha yang tersedia. Hasil analisis data yang menunjukkan bahwa tenaga kerja yang terserap pada usaha kecil non pertanian di dua lokasi penelitian berjumlah 385 orang, tersebar pada 16 jenis usaha yang mencakup 211 unit usaha. Persentase terbanyak $(65,45 \%)$ tenaga kerja terserap pada kelompok usaha industri kecil/rumah tangga dengan 4 jenis usaha, kemudian kelompok usaha jasa dengan 7 jenis usaha menyerap tenaga kerja $21,30 \%$, sedangkan kelompok usaha perdagangan dengan 5 jenis usaha menyerap $13,25 \%$ total tenaga kerja.

Kontribusi usaha kecil non pertanian terhadap kesempatan kerja di dua lokasi penelitian memberikan gambaran bahwa usaha kecil non pertanian merupakan alternatif yang cukup strategis dalam rangka mengatasi masalah kesempatan kerja di pedesaan karena secara langsung dapat menciptakan peluang kerja baru dan mampu menyerap banyak pekerja. Usaha kecil non pertanian dapat mengatasi masalah lapangan kerja di pedesaan karena tenaga kerja yang tidak terserap di sektor primer (pertanian) dapat memanfaaatkan peluang kerja di sektor sekunder (khususnya industri kecil), dan sektor tersier (perdagangan dan jasa).

\section{SARAN}

Berbagai sarana prasarana yang mendukung pengembangan aktivitas ekonomi usaha kecil non pertanian di Desa Tibobo dan Desa Borona perlu dilengkapi secara memadai agar masyarakat dapat memanfaatkan berbagai peluang usaha dalam rangka perluasan kesempatan kerja.

Hasil penelitian ini dapat dijadikan rangsangan bagi penduduk di Desa Tibobo dan Desa Borona agar lebih meningkatkan dan mengembangkan usaha-usaha kecil non pertanian. Karena itu pengelolaan usaha-usaha yang telah ada perlu lebih dikembangkan sehingga dapat memberikan kontribusi yang lebih besar terhadap kesempatan kerja bagi masyarakat. Dalam kaitan ini, perhatian pihak pemerintah sangat diharapkan untuk memfasilitasi baik dalam bentuk bimbingan dan pengawasan maupun pemberian bantuan berbagai fasilitas khususnya modal usaha yang dapat mendukung pengembangan usaha masyarakat.

\section{DAFTAR PUSTAKA}

Amwar, D. 2014. Kinerja Usaha Kecil Non Pertanian Dan Keberadaan Institusi Keuangan Mikro.

Aninditya, D., Banowati, E., \& Sriyanto, S. 
2020. Pengaruh Pengetahuan dan Perilaku Petani dalam Memelihara Saluran Irigasi di Desa Kunjeng Kecamatan Gubug Kabupaten Grobogan. Edu Geography, $8(3), 174-181$.

Ardiansyah, M., Zuhroh, I., \& Abdullah, M. F. 2018. Analisis Penyerapan Tenaga Kerja Sektor Industri Pengolahan Tahun 20012015 di Pasuruan dan Sidoarjo. Jurnal Ilmu Ekonomi JIE, 2(2), 294-308.

Harmadi, S. H. B., \& Tjiptoherijanto, P. 2009.

Prediksi Ketenagakerjaan dan Sektor Pertanian di Indonesia Tahun 2009 serta Antisipasi Terhadap Ancaman Krisis Global. Jurnal Kependudukan Indonesia, 4(2), 1-14.

Purwanto, E. A. 2007. Mengkaji potensi usaha kecil dan menengah (UKM) untuk pembuatan kebijakan anti kemiskinan di Indonesia. Jurnal Ilmu Sosial Dan Ilmu Politik, 10(3), 295-324.

Suhariyanto, K. 2007. Kinerja dan Perspektif Kegiatan non-Pertanian dalam Ekonomi Perdesaan. Makalah Disampaikan Pada Seminar Nasional Dinamika Pembangunan Pertanian Dan Perdesaan: Mencari Alternatif Arah Pembangunan Ekonomi Rakyat, 4. 